\title{
Evaluation of Female Condom Use among Students at the University of Lubumbashi: Knowledge, Attitude and Practice on University Cities
}

\section{Mujanayi Mujanayi Jean Bernard1, Ilunga Kandolo Simon'2*, Matungulu Matungulu Charles², Kaya Mulumbati Charles ${ }^{3}$, Mashini Ngongo Ghislain'3, Mwembotambwe Ankoy Albert ${ }^{3}$, Kabyla Ilunga Benjamin ${ }^{3}$, Kalengamwenze Kayamba Prosper ${ }^{3}$}

\author{
${ }^{1}$ The Ilebo General Hospital, Kasai, Congo \\ ${ }^{2}$ School of Public Helth, University of Lubumbashi, Lubumbashi, Congo \\ ${ }^{3}$ Faculty of Medecine, University of Lubumbashi, Lubumbashi, Congo \\ Email: ^silungak@gmail.com
}

\begin{abstract}
How to cite this paper: Bernard, M.M.J. Simon, I.K., Charles, M.M., Charles, K.M., Ghislain, M.N., Albert, M.A., Benjamin, K.I. and Prosper, K.K. (2017) Evaluation of Female Condom Use among Students at the University of Lubumbashi: Knowledge, Attitude and Practice on University Cities. Open Access Library Journal, 4: e4129. https://doi.org/10.4236/oalib.1104129
\end{abstract}

Received: November 7, 2017

Accepted: November 25, 2017

Published: November 28, 2017

Copyright $\odot 2017$ by authors and Open Access Library Inc.

This work is licensed under the Creative Commons Attribution International License (CC BY 4.0).

http://creativecommons.org/licenses/by/4.0/

(c) (i) Open Access

\begin{abstract}
Introduction: The use of the female condom is still very low on university campuses. This study was conducted to assess the knowledge, attitudes and practices of female condom use in Lubumbashi. Method: We conducted a cross-sectional study on the use of the female condom on university campuses. Our sample consisted of 300 individuals, including 169 women and 131 men. A questionnaire was established to collect the data. SPPS version 23 helped us analyze the data, which was encoded in Excel. Results: Female condom use was reported in 137 women, or $81.1 \%$ of women had previously used the female condom (chi-square $=25.237$ ). Single women were more likely than brides to use female condoms. Women who did not use female condoms were luckier than those who used it because they did not receive the information. Conclusion: Information on the existence of the female condom and the marital status of the survey influences the use of the female condom. Popularization about the existence of the female condom and its availability on university campuses are important steps to take for its use. Appropriate health education would be the key to popularize and promote the female condom.
\end{abstract}

\section{Subject Areas \\ Public Health}




\section{Keywords}

Female Condoms, Contraception, University Cities, Lubumbashi, DRC

\section{Introduction}

In the former USSR at Alma Ata from 6 to 12 September 1978, WHO and UNICEF adopted the following definition of primary health care (PHC):

"Primary Health Care is essential health care based on practical, scientifically valid and socially acceptable methods and techniques, made universally accessible to all individuals and families in the community with full participation and cost that the community and the country can assume at all stages of their development in a spirit of self-responsibility and self-determination" [1].

Essential PHC care includes curative, preventive, promotional and rehabilitative activities that are grouped as components, including the control of local epidemics and endemics including Sexually Transmitted Infections as well as maternal and child health.

The literature at our fingertips shows that other regions have made significant progress in the fight against HIV/AIDS, yet the pandemic remains a serious threat to public health.

The female condom is both a means of mechanical contraception and a means of protection against sexually transmitted infections (STIs). This condom gives the woman to decide for herself how to use this method of contraception and protection against STIs [2].

The increasing number of cases of HIV infection and the specific vulnerability of women call on prevention actors to consider all possible ways to strengthen women's resources to enable them to act more autonomously in the context of HIV/AIDS framework for the protection of sexual relations [3].

Despite the decline in the seroprevalence rate, AIDS remains a public health problem, and is also considered to be a phenomenon at the base of social exclusion in some societies around the world. It is in essence a sexually transmitted disease and its emergence is one of the most striking social events since the end of the twentieth century. In addition, about 570.000 people live with HIV/AIDS, including 530.000 adults ( 15 - 45 years) and 40,000 children ( 0 - 14 years), including 46.600 deaths and 420.943 AIDS orphans [4].

Is the opposition of the partner, the desire to conceive, the obstacles to the use of the female condom?

\section{Methodology}

We conducted a cross-sectional descriptive study of students housing Homes I for men and Home II for girls in cities during the period from 10 March to 30 August 2017 in the Kassapa health area in the Health District of Lubumbashi of Upper Katanga, province, in the Democratic Republic of Congo. 
The study population consists only of students housing Homes I and II of Lubumbashi's university campuses in the Kassapa health area in the Lubumbashi Health District, Lubumbashi City, DR Congo's Upper Katanga Province.

Our sampling is in cluster. The student homes were considered as clusters and two of them were randomly selected. We thus included all the students living in the two homes taken as cluster in our study on the university cities. We included 300 students (All who are living in the two clusters) for both sexes combined and 167 for females.

A questionnaire was used to collect data that was analyzed by the SPSS software, version 23 .

\section{Results}

Given the results of this, of the 300 students involved in our study, we observed 169 female students, $56.3 \%$ against 131 students or $43.7 \%$.

In terms of marital status, 270 respondents were single or $90 \%$ against 30 married or $10 \%$.

The minimum age of students was 18 years while the maximum age was 42 years. The age group between 18 and 24 years accounted for $59.3 \%$ or 178 people against that of over 24 years with $40.7 \%$ or 122 people.

With regard to the cycles of the studies surveyed, those of the first cycle represent $64 \%$ against $36 \%$ for the second cycle out of a total of 300 participants (Table 1).

Regarding information on the existence of the female condom 238 people or $79.3 \%$ were informed against $62(20.7 \%)$ who had never heard of the female condom.

Regarding the use of the female condom according to religions, we found that Catholic Christians came in first place with $39.1 \%$ followed by other churches with $34.9 \%$. Protestants come third with $20.1 \%$. Muslims account for $5.9 \%$ (Table 2).

As for the use of the female condom 264 participants or $88 \%$ had already used against 36 people or $12 \%$ had never used it (Table 3 ).

Table 1. Distribution of students by socio-demographic data.

\begin{tabular}{cccc}
\hline & & $\mathrm{N}=300$ & Percentage \\
\hline \multirow{2}{*}{ Sex } & Female & 169 & 56.3 \\
& Male & 131 & 43.7 \\
Civil status & Unmarried (Single) & 270 & 90 \\
& married & 30 & 10 \\
Age & $18-24$ ans & 178 & 59.3 \\
& $>24$ ans & 122 & 40.7 \\
Study levels & Under graduation & 192 & 64 \\
& Graduation & 108 & 36 \\
\hline
\end{tabular}


The Table 4 on the distribution of female students by socio-demographic characteristics shows that 150 women or $88.8 \%$ were single compared to $11.2 \%$ who were married or 19 women. The age group between 18 and 24 comes in first place with $62.7 \%$ against $37.3 \%$ of students who are over 24 years old. Compared to cycles, undergraduate students account for $67.5 \%$.

We found that 20 female students had never heard of the female condom or $11.8 \%$ and 149 out of 169 had already heard of the female condom $88.2 \%$ (Table $5)$.

Table 2. Distribution of students by information on the existence of the female condom.

\begin{tabular}{ccc}
\hline Status & Frequency & Percentage \\
\hline NO & 62 & 20.7 \\
YES & 238 & 79.3 \\
Total & 300 & 100.0 \\
\hline
\end{tabular}

Table 3. Distribution of students according to the yes or no use of the female condom.

\begin{tabular}{ccc}
\hline Status & Frequency & Percentage \\
\hline NO & 36 & 12.0 \\
YES & 264 & 88.0 \\
Total & 300 & 100.0 \\
\hline
\end{tabular}

Table 4. Sociodemographic data of female students.

\begin{tabular}{cccc}
\hline & & $\mathrm{N}=169$ & Percentage \\
\hline \multirow{2}{*}{ Civil status } & Singles & 150 & 88.8 \\
& Married & 19 & 11.2 \\
Age & $18-24$ years & 106 & 62.7 \\
& $>24$ years & 63 & 37.3 \\
Study level & Under graduation & 114 & 67.5 \\
& Graduation & 55 & 32.5 \\
& Other & 59 & 34.9 \\
Religion & Catholic & 66 & 39.1 \\
& Muslim & 10 & 5.9 \\
& Protestant & 34 & 20.1 \\
\hline
\end{tabular}

Table 5. Distribution of female students on the knowledge of the existence of the female condom.

\begin{tabular}{ccc}
\hline Knowledge & Frequency & Percentage \\
\hline NO & 20 & 11.8 \\
YES & 149 & 88.2 \\
Total & 169 & 100.0 \\
\hline
\end{tabular}


Despite the benefits of the female condom compared to the male condom, $18.9 \%$ of female students never used it (Table 6).

The Table 7 on the distribution of female students on female condom preference shows that out of the 169 respondents $66.9 \%$ have a preference for the male condom compared to $33.1 \%$ who have a preference for the female condom.

This table shows that only $33 \%$ of respondents encourage others to use the female condom (Table 8).

Regarding the reuse of the female condom, out of 169 students, 137 used the female condom among which 37 reused it or $27 \%$ as shown in Figure 1. This is due to lack of information on its unique use and the risks they run.

Table 6. Distribution of female students on female condom use.

\begin{tabular}{ccc}
\hline USE & Frequency & Percentage \\
\hline NO & 32 & 18.9 \\
YES & 137 & 81.1 \\
Total & 169 & 100.0 \\
\hline
\end{tabular}

Table 6. Female students' distribution of female condom use shows that $81.1 \%$ use it compared to $18.9 \%$ who do not use it.

Table 7. Distribution of female students on female condom preference.

\begin{tabular}{ccc}
\hline Preference & Frequency & Percentage \\
\hline Female & 56 & 33.1 \\
Male & 113 & 66.9 \\
Total & 169 & 100.0 \\
\hline
\end{tabular}

Table 8. Distribution of female students on the encouragement of the female condom.

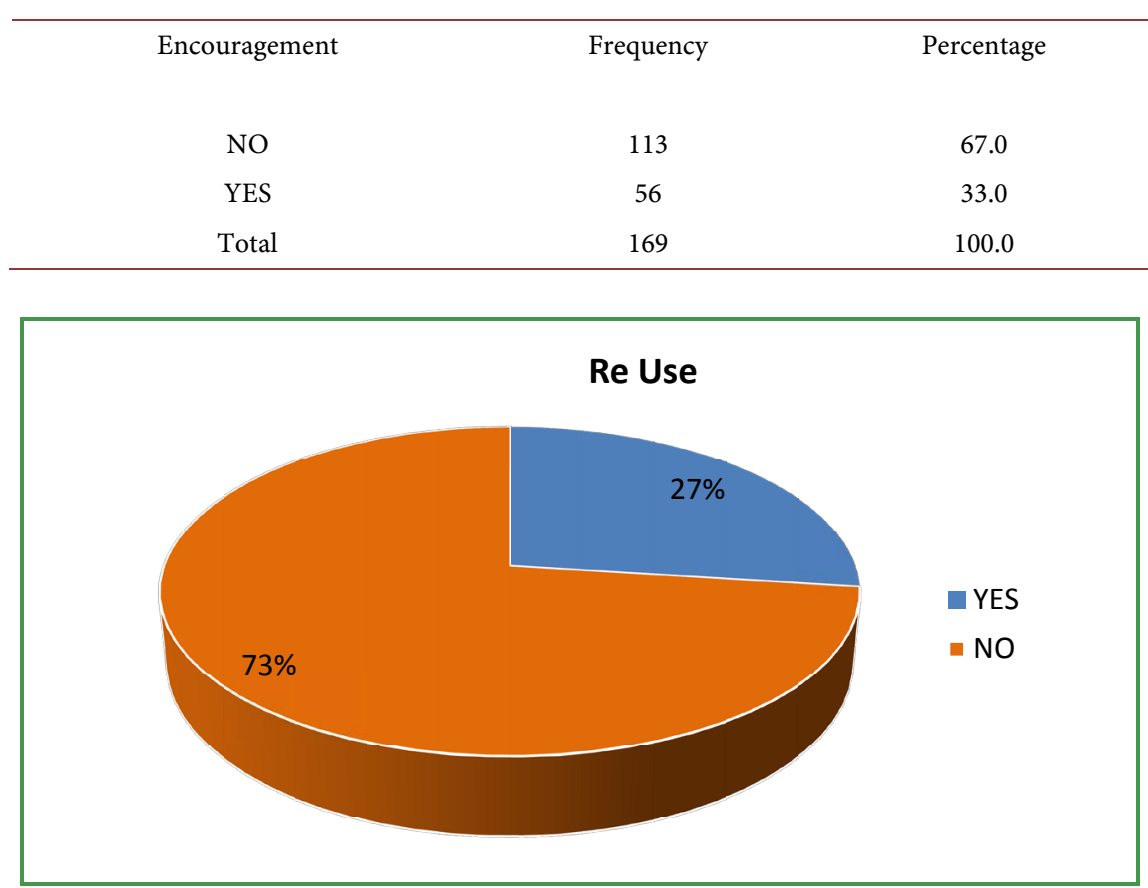

Figure 1. the reuse of the female condom by students. 
Regarding the reuse of female condom, the Figure 2 shows that soap is used to wash female condom by women who reused female condom.

Table 9 shows that unmarried students are more likely than female condoms.

Women who do not use the female condom are more likely than those who use it to have not been informed about the female condom. The lack of information on the existence of the female condom has a strong influence on its use (Table 10).

\section{Discussion}

In this part of the work we will present our results and compare them to those of others.

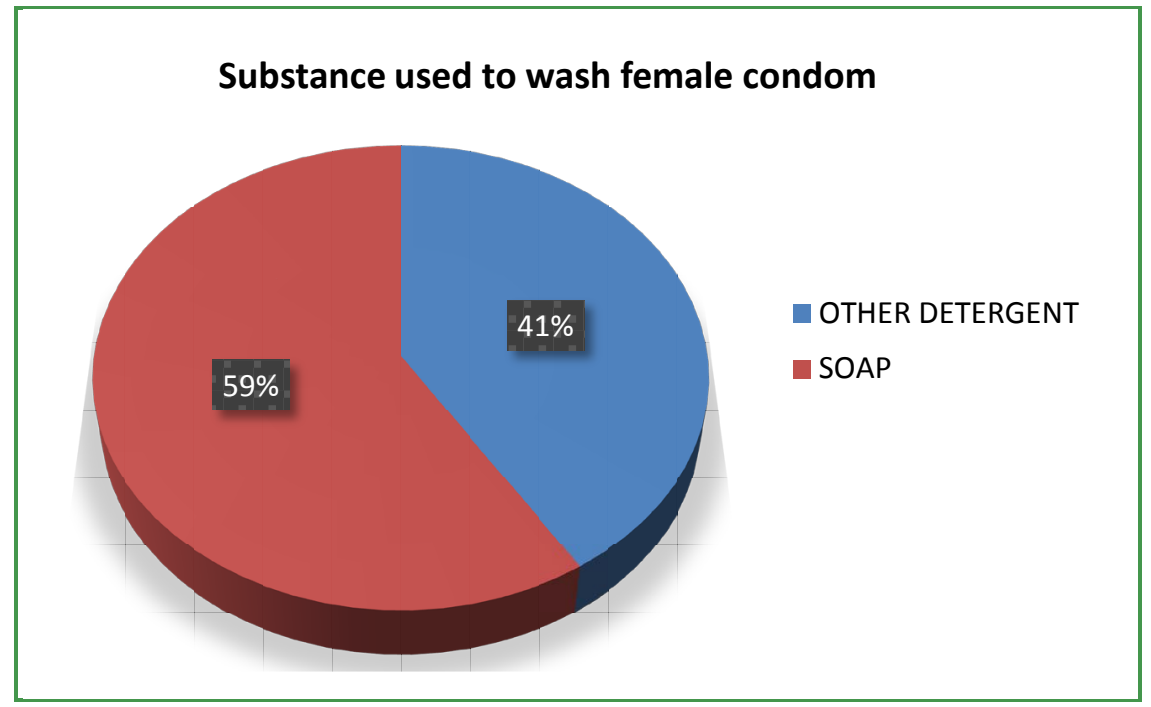

Figure 2. Substance used to wash female condom before reuse.

Table 9. The use of the female condom and the marital status of female students.

\begin{tabular}{|c|c|c|c|c|c|c|}
\hline & Use & & & & & \\
\hline \multirow[t]{2}{*}{ CIVIL STATUS } & YES & NO & Total & OR & IC & $\mathrm{P}$ \\
\hline & & & & 3.851 & $1.221 ; 12.144$ & 0.000 \\
\hline SINGLE & 76 & 74 & 150 & & & \\
\hline MARRIED & 4 & 15 & 19 & & & \\
\hline Total & 80 & 89 & 169 & & & \\
\hline
\end{tabular}

Table 10. Use of the female condom and information on the female condom.

\begin{tabular}{|c|c|c|c|c|c|}
\hline \multicolumn{6}{|c|}{ USE } \\
\hline INFORMATION & NON & OUI & Total & Khi-deux & IC \\
\hline NON & 20 & 0 & 20 & 25.237 & $2.042 ; 3.020$ \\
\hline OUI & 60 & 89 & 149 & & \\
\hline Total & 80 & 89 & 169 & & \\
\hline
\end{tabular}


The female condom is both a means of mechanical contraception and a means of protection against sexually transmitted infections (STIs). This condom gives the woman the opportunity to decide for herself how to use this method of contraception and protection against STIs [2].

Among the participants in the study (300), 169 were female (56.3\%) versus 131 (43.7\%) were male (Table 1). Our results are similar to those found in Nigeria or in a study on the female condom, women were the majority with $51.9 \%$ against those of the male with $48.1 \%$ [5].

In terms of marital status, 270 respondents were single or $90 \%$ against 30 married or $10 \%$. In Zambia a study on acceptability, knowledge and beliefs about circumcision and the female condom reveals that $35 \%$ of respondents were married [6].

The minimum age of the respondents was 18 years while the maximum age was 42 years. The age group between 18 and 24 years accounted for $59.3 \%$ or 178 people over the age of 24 with $40.7 \%$ or 122 people.

$64 \%$ of the participants had the under-graduation level against $36 \%$ for the for the graduation level.

Regarding the information on the existence of the female condom 238 people or 79.3 people were informed against $62(20.7 \%)$ people who had never heard of it.

As for the use of the female condom 264 people or $88 \%$ had already used against 36 people or $12 \%$ had never used it.

Regarding the distribution of female students by age group, we find that the age group between 18 and 24 years was the majority with $62.7 \%$ against $37.3 \%$ of the respondents who were over 24 years old. Our results are different from those found in Zimbabwe where the age group between 15 and 18 years was the majority [7].

Regarding the use of the female condom according to religion we found that Christian Catholics came in first place with $39.1 \%$ followed by women from other churches with $34.9 \%$. Protestants come third with $20.1 \%$. Muslim women represent 5.9\% (Table 4: Sociodemographic data). In Ethiopia, a study on the use of the female condom shows that $42.4 \%$ of female students were of Orthodox Christianity [8]. Okunlola in his study conducted at the University teaching Hospital of Ibadan in Nigeria among employees of the center found that Christians used more female condom followed by Muslims and followers of other religions with respectively $69.1 \%, 39.1 \%$ and $0.8 \%$ [9].

The Table 5 shows that 20 female students had never heard of the female condom or $11.8 \%$ and 149 out of 169 had already heard of the female condom $88.2 \%$. Our results are almost similar to those of Chipfuwa on female condom use in the central province of Zimbabwe, which shows that $36.3 \%$ of participants had never heard of the female condom and $83.5 \%$ had never used it [10]. In South-eastern Nigeria, however, a survey of undergraduate students indicates that the level of knowledge about the female condom is $76.7 \%$ among the students surveyed [11]. Okunlola found that in Nigeria that $81.4 \%$ of women had 
knowledge about the female condom [9].

Table 6 on the distribution of female students regarding female condom use shows that $81.1 \%$ use it against $18.9 \%$ who do not use it.

Table 7 on the distribution of women on female condom preference shows that of the 169 respondents, $66.9 \%$ have a preference for the male condom compared to $33.1 \%$ who have a preference for the female condom.

Only $33.0 \%$ of women encourage others to use the female condom as shown in Table 8. Mutowo study says $76.3 \%$ of women encourage others to use female condoms [7].

Table 9 shows that single women are more likely than brides to use female condoms $(\mathrm{OR}=3.851, p=0.000)$.

Women who do not use the female condom are more likely than those who use it to be unaware of the female condom (chi-square $=25.237$ ) as shown in Table 9.

Regarding the reuse of the female condom, out of 169 women included in our study, 137 had used it while 37 had reused it or $27 \%$. Audrey, in his study on the acceptability of the reuse of the female condom among women in southern urban areas finds that $83 \%$ say they can reuse them and $45 \%$ say they reuse it up to 7 to 8 times [12].

Figure 2 indicates that 22 out of 37 respondents who reused the female condom, or 59\%, had used the soap before reuse. Audrey reports in her study that almost $99 \%$ of the women who participated in her study use liquid soap to clean the female condom before reusing it [12]. Based on the recommendations of the January 2002 consultation, WHO does not recommend or promote reuse of female condoms [13].

\section{Conclusion}

We conducted a cross-sectional study of attitude and practice knowledge about female condom use in university campuses at the University of Lubumbashi in the Democratic Republic of Congo. Three hundred men and women were included in our study, of which 106 women (62.7\%) belong to the 18 - 24 age group, $39.1 \%$ were Catholic; 114 women or $67.5 \%$ were undergraduate; 20 female students had never heard of the female condom $11.8 \%$ and 149 out of 169 had already heard of the female condom $88.2 \%$; women who do not use female condoms are more likely than those who use it to have not received the information $($ chi-square $=25.237)$.

\section{Ethical Clearance}

This work has been approved by the Ethics Committee of the University of Lubumbashi as well.

\section{Limitations about This Study}

The Ideal was to do an interview, it was not possible because the students did not 
accept it.

\section{Conflict}

Authors declared they have no conflict of interest.

\section{References}

[1] Van Lerberghe, W., Evans, T. and Rasanathan, K. (2008) Public Policies for Public Health. In: Van Lerberghe, W., Ed., Le Rapp. on Health in the World Now More Than Ever, WHO Press, Geneva, 63-80.

[2] OPALS (2010) Study of Female Condom Acceptance by Sex Workers and Role of Training.

[3] Déogratias Mazina, V.M. (2002) The Female Condom.

[4] CNLCS (2010) National Strategic Plan for the Fight against HIV/AIDS 2006-2010. JUNE 2006, 1-161.

[5] Avaezi, O. (2014) Repetitive Risk Reduction Counseling on Condom Use among HIV Exposed Sero-negative (HESN) Persons in Jos, Nigeria. AIDS Research and Human Retroviruses, 30, A200. https://doi.org/10.1089/aid.2014.5431.abstract

[6] Jones, D., et al. (2014) Acceptability, Knowledge, Beliefs, and Partners as Determinants of Zambian Men's Readiness to Undergo Medical Male Circumcision. AIDS and Behavior, 18, 278-284. https://doi.org/10.1007/s10461-013-0530-0

[7] Mutowo, J., Kasu, C.M. and Mufunda, E. (2014) File. Pan African Medical Journal, 17, 1-7.

[8] Feyissa, G.T., Abebe, L., Girma, E. and Woldie, M. (2012) Stigma and Discrimination against People Living with HIV by Healthcare Providers, Southwest Ethiopia. BMC Public Health, 12, 522. https://doi.org/10.1186/1471-2458-12-522

[9] Okunlola, M.A., Morhason-Bello, I.O., Owonikoko, K.M. and Adekunle, A.O. (2006) Female Condom Awareness, Use and Concerns among Nigerian Female Undergraduates. Journal of Obstetrics and Gynaecology, 26, 353-356. https://doi.org/10.1080/01443610600613516

[10] Chipfuza, M. and Ancia, T. (2014) Level of Awareness and Uptake of the Female Condom in Women Aged 18 to 49 Years in Bindura District, Mashonaland Central Province, Zimb Abwe. African Journal of AIDS Research, 13, 7.

[11] Ikeako, L.C., Ezegwui, H.U., Mba, S., Iyioke, C.A. and Okeke, T.C. (2015) Prevalence and Factors Associated with Use of the Female Condom among Undergraduates in a University in Enugu, South East Nigeria., Vol. 8, 532-540.

[12] Pettifor, A.E., Beksinska, M.E., Rees, H.V., Mqoqi, N. and Dickson-Tetteh, K.E. (2001) The Acceptability of Reuse of the Female Condom among Urban South African Women. Journal of Urban Health, 78, 647-657. https://doi.org/10.1093/jurban/78.4.647

[13] World Health Organization (2002) WHO Information Update: Considerations regarding Re-Use of the Female Condom. July 2002, WHO, Geneva. 
Submit or recommend next manuscript to OALib Journal and we will provide best service for you:

- Publication frequency: Monthly

- 9 subject areas of science, technology and medicine

- Fair and rigorous peer-review system

- Fast publication process

- Article promotion in various social networking sites (LinkedIn, Facebook, Twitter, etc.)

- Maximum dissemination of your research work

Submit Your Paper Online: Click Here to Submit

Or Contact service@oalib.com 